\title{
Diversity and singularity of the avifauna in the austral peat bogs of the Cape Horn Biosphere Reserve, Chile
}

\author{
José Tomás Ibarra ${ }^{2}$, Christopher B. Anderson², Tomás A. Altamirano, \\ Ricardo Rozzi ${ }^{2}$, and Cristián Bonacic ${ }^{1}$ \\ 'Laboratorio Fauna Australis, Facultad de Agronomía e Ingeniería Forestal, Pontificia Universidad Católica \\ de Chile, Casilla 306-22, Santiago, Chile. \\ ${ }^{2}$ Parque Etnobotánico Omora (Instituto de Ecología y Biodiversidad, Universidad de Magallanes), Reserva \\ de Biosfera Cabo de Hornos, Puerto Williams, Chile. \\ ${ }^{3}$ Department of Philosophy and Religion Studies, University of North Texas, Denton, Texas, USA.
}

\begin{abstract}
Ibarra, J.T., C.B. Anderson, T.A. Altamirano, R. Rozzi, and C. Bonacic. 2010. Diversity and singularity of the avifauna in the austral peat bogs of the Cape Horn Biosphere Reserve, Chile. Cien. Inv. Agr. 37(1): 29- 43. Sphagnum-dominated peat bogs that are strongly embedded within the southern temperate forest matrix are increasingly being used for agriculture. Nevertheless, little is known about their biodiversity. Moreover, the remote areas of southern

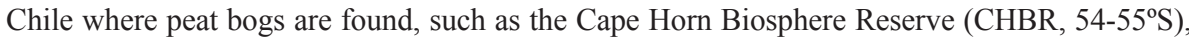
where birds are the most diverse and best represented group of vertebrates, have not been wellinvestigated. With the aim to broaden this knowledge in the CHBR, we studied the diversity of the avian assemblage in peat bogs on Navarino Island. We compared the composition of avian species between wetlands with and without peat bogs to test if Sphagnum bogs represented a singular habitat for birds in this area. Furthermore, the 37 bird species recorded in these habitats were classified according to guild structure. The community similarity values showed that peat bogs hosted a bird composition that was different from that present in wetlands without Sphagnum, suggesting that peat bogs are a singular type of habitat for birds in the CHBR. The most frequently feeding groups recorded in these wetlands were insectivores (48.7\%), followed by omnivores (23.1\%). Our results showed that, in contrast to previous studies of birds in peat bogs, these environments constituted a distinct wetland habitat for feeding, reproduction and sheltering for some species in the CHBR. Thus, plans for the conservation and rational use of peat ecosystems should consider the high value of these habitats for biodiversity on a landscape scale, especially for birds of the southernmost extreme of the Americas.
\end{abstract}

Key words: Assemblage, Cape Horn Biosphere Reserve, Navarino Island, Patagonia, Sphagnum spp., wetlands.

\section{Introduction}

Sphagnum-dominated peat bogs are being increasingly used in extractive industries, such as

Received 10 March 2009. Accepted 15 July 2009.

Corresponding author: jtibarra@uc.cl the removal of the organic layer of peat for agricultural uses because of its high quality as a substrate for horticulture, floriculture, fruticulture, clearings and hydroponic activities (de la Balze et al., 2004). Peat is also used as a cover that improves other soils and as organic matter for the cultivation of fungi (Arroyo et al., 2005). The third article of the Chilean Organic Law consid- 
ers peat to be a mining resource, licensable for exploitation to any interested party (Henríquez, 2004), although anyone planning to exploit peat is now obliged to undergo an environmental impact study (Hauser, 1996). Lappalainen (1996) estimates that $1,400,000$ ha of peat bogs (c. 33\% of the total surface of the wetlands) are potentially exploitable in the Aysén and Magallanes Regions of southern Chile.

Peat bogs are embedded throughout the southern temperate forest matrix in southern SouthAmerica (Arroyo et al., 2005), and they are the result of high precipitation and low temperatures (Roig et al., 2001). Wetland environments cover $23.5 \%$ of the total surface of the Magallanes and the Chilean Antarctic Region, where peat bogs are the most representative type of wetland (Arroyo et al., 2005), reaching 800,000 ha (Henríquez, 2004). In the Cape Horn Biosphere Reserve (CHBR, 54 to $55^{\circ} \mathrm{S}$ ), vast terrestrial zones are covered by peat bogs dominated by Sphagnum spp., particularly the southern and western portions of the archipelago (Rozzi et al., 2006).

Similarly, birds are an abundant and diverse portion of the biotic assemblage in the CHBR (Venegas and Sielfeld, 199; Anderson et al., 2006). The first ornithological studies in these Sub-Antarctic environments covered different islands of the archipelago south of the Beagle Channel (e.g., Oustalet, 1891; Reynolds, 1935; Olrog, 1950; Barros 1971, 1976; Sielfeld, 1977; Venegas, 1981, 1991; Venegas and Sielfeld, 1998). However, none were focused on the ecology of birds inhabiting peat bogs. After these surveys, and principally during the last decade because of the establishment of the Omora Sub-Antarctic Bird Observatory, knowledge about forest birds has increased substantially in Cape Horn, specifically on Navarino Island (e.g., Anderson and Rozzi, 2000; Anderson et al., 2002; McGehee et al., 2004; Ippi and Rozzi, 2004; McGehee and Eitniear, 2006; Brown et al., 2007; McGehee and Eitniear, 2007a, 2007b, Ippi et al., 2009). Nevertheless, the bird assemblages that use peat bog habitats in this area have not yet been studied, unlike the zones north of the Magallanes Region $\left(51^{\circ}\right.$ to $\left.53^{\circ} \mathrm{S}\right)$ such as Puerto Natales and Tierra del Fuego (TDF) (e.g., Humphrey et al., 1970;
Venegas, 1976; Venegas and Jory, 1979; Guzmán et al. 1986; Blanco et al., 2004; Schlatter, 2004).

Therefore, the scarcity of knowledge about the ecology of bird assemblages that use peat bogs south of TDF, the vast extent of the peat bog environment in the area, and the availability of peat bogs for licensable exploitation makes peat bogs and their biodiversity subjects for priority study in the CHBR. It also bears mentioning that this area has been identified as one of the 24 remaining "pristine wilderness areas" in the world (Mittermeier et al., 2002); however, it is under increasing pressures due to growing connectivity, urban growth, alien species invasion and tourism development (Anderson et al., 2006; Rozzi et al., 2006; Arango et al., 2007; Ibarra et al., 2009a; Schüttler et al., 2010).

In this context, the objectives of this study were: i. to determine the species composition, richness, and relative abundances of birds using Sphagnum-dominated peat bog wetlands, ii. to explore whether bird composition in Sphagnum peat bogs differs from wetlands without Sphagnum, to determine whether peat bogs represent a distinct habitat for birds in this landscape, and iii. to carry out classification according to habitat requirements, guild structure and the most frequent activities for bird species inhabiting peat bogs in the CHBR.

\section{Materials and methods}

\section{Study area}

The study was carried out on Navarino Island $\left(54^{\circ} 55^{\circ} \mathrm{S}, 67^{\circ} \mathrm{W}, 2,528 \mathrm{~km}^{2}\right)$, which is part of the CHBR (Figure 1). The area has a mean annual temperature of $6^{\circ} \mathrm{C}$ and rainfall of 467.3 mm (di Castri and Hajek, 1976). The eco-region belongs to the Sub-Antarctic Magellanic forests, where the mosaic of different habitats includes: 1. evergreen forests; 2 . deciduous forests; 3. high-Andean habitats; 4. tundra formations (which include Sphagnum-dominated peat bogs); and 5. freshwater ecosystems (Pisano, 1977). 


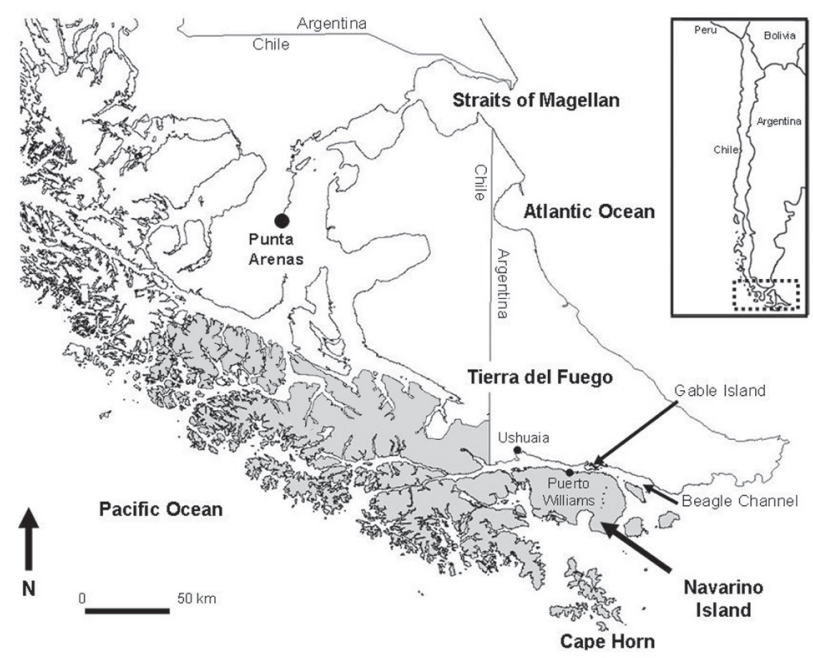

Figure 1. Map of southern South America, showing the Cape Horn Biosphere Reserve (in gray). Study sites were located on Navarino Island (54-55 $\mathrm{S})$, Chile.

Regarding peat bogs, Sphagnum magellanicum is the dominant bryophyte species in these formations (Rozzi et al., 2006). In some cases, Nothofagus antarctica, a tree species adapted to flooded zones, and Marsippospermum grandiflorum, are also present (Moore, 1983). The peat bog-forest ecotone includes tree species like $N$. pumilio and $N$. betuloides, which never reach a growth that is comparable to forest sites (Sielfeld, 1977). In peat bog-shrub ecotones, bush species like Berberis buxifolia, B. ilicifolia, Chiliotrichum diffusum, and Empretrum rubrum are also present. Finally, there are several sites presenting peat bog-grassland transitions.

\section{Bird sampling}

A total of 49 wetlands were surveyed on Navarino Island in preliminary avian surveys. Next, a random subsample of 10 wetlands was selected for systematic bird sampling. These 10 wetlands were identified as natural lentic waterbodies ("natural lentic"), following the classification system proposed by Ramírez and San Martín (2006). These authors categorized peat bogs and other types of wetlands that were exclusively freshwater and flooded. Accordingly, five wetlands surrounded by a Sphagnum matrix (i.e., Sphagnum-dominated peat bogs, wetlands 3, 4, 5,6 , and 7 in this study), and five without peat bogs (wetlands 1, 2, 8, 9, and 10) were sampled (Table 1). All sites were situated between sea level and an elevation of $379 \mathrm{~m}$, and they were separated by a minimum distance of $1.5 \mathrm{~km}$ and a maximum distance of $7.5 \mathrm{~km}$.

During 2006, we conducted a seasonal sampling of birds to obtain the best representation of the avian assemblages because there is high bird dynamism in the area throughout the year (Ibarra et al., 2009b). However, the compositional statistical analysis (i.e., a comparison between the assemblages found in wetlands that were or were not within peat bogs) was concentrated only on the breeding season, as all bird species recorded 
Table 1. General characteristics of ten wetlands studied on Navarino Island, Cape Horn Biosphere Reserve, Chile.

\begin{tabular}{|c|c|c|c|}
\hline Wetland number & Geographic position UTM ${ }^{1}$ & Pond size, ha & Sphagnum peat bogs ${ }^{2}$ \\
\hline \multirow[t]{2}{*}{1} & 3911991 & 7.38 & \\
\hline & 594707 & & \\
\hline \multirow[t]{2}{*}{2} & 3912036 & 23.84 & \\
\hline & 586920 & & \\
\hline \multirow[t]{2}{*}{3} & 3911164 & 2.44 & $\mathrm{X}$ \\
\hline & 587149 & & \\
\hline \multirow[t]{2}{*}{4} & 3910637 & 3.04 & $\mathrm{X}$ \\
\hline & 588622 & & \\
\hline \multirow[t]{2}{*}{5} & 3912079 & 1.48 & $\mathrm{X}$ \\
\hline & 581337 & & \\
\hline \multirow[t]{2}{*}{6} & 3916006 & 0.83 & $\mathrm{X}$ \\
\hline & 566397 & & \\
\hline \multirow[t]{2}{*}{7} & 3912282 & 2.93 & $\mathrm{X}$ \\
\hline & 563368 & & \\
\hline \multirow[t]{2}{*}{8} & 3912708 & 12.04 & \\
\hline & 564743 & & \\
\hline \multirow[t]{2}{*}{9} & 3912265 & 20.9 & \\
\hline & 573934 & & \\
\hline \multirow[t]{2}{*}{10} & 3906193 & 6.13 & \\
\hline & 583626 & & \\
\hline
\end{tabular}

in the breeding season were present during the non-breeding season as well.

Bird species and individuals were recorded in each wetland between 6:00 a.m. and 11:30 a.m. The number of individuals belonging to each bird species was identified and recorded by the bird vocalizations or using binoculars $(10 \times 30$ and 10x42). Sampling stations with a variable radius of $25 \mathrm{~m}$ were used (Ralph et al., 1995; González and Victoriano, 2005). To obtain a good representation of the habitats adjacent to bodies of water, the location where these habitats show if they are actually embedded in a Sphagnum-dominated peat bog or not, 12 sampling stations were arranged per wetland. These stations were configured systematically and separated by a distance of at least $100 \mathrm{~m}$, to avoid recording of the same individuals in neighboring stations (Bibby et al., 1992; Rozzi et al., 1996a). Sampling stations were arranged in four $200 \mathrm{~m}$ transects, starting from the edge of each body of water, established according to the cardinal points. Therefore, the first station was placed in each transect at the edge of the water surface (north, south, east and west), and from that station the other two stations were established at 100 and $200 \mathrm{~m}$ from the edge of the body of water inwards. Wetlands were actually considered "Sphagnum-dominated peat bogs" 
if at least $70 \%$ of the stations at 100 and 200 $\mathrm{m}$ from the shore were established over Sphagnum spp. The remaining sampling stations $(<30 \%)$ of Sphagnum-dominated peat bog wetlands were mainly present in either bog-forest, bog-shrub or bog-grassland ecotones.

Birds heard or observed from the center of the station were recorded during a period of $5 \mathrm{~min}$, and their activity was described as: resting or swimming, flying, alarming, feeding, fighting, courting or vocalizing, (Ralph et al., 1995; Rozzi et al., 1996b). The vocalizing (i.e., sound record) category was attributed to a species when it was only identified by its vocalization, without determining its specific activity. A total of 2,400 min of bird sampling were completed.

Finally, guild structure of the assemblage was determined for aquatic and aquatic/terrestrial birds recorded in peat bogs. Microhabitat associations were determined by means of direct observation (species present on shores, seacoasts, open waters or rushes at the moment of its registration). Feeding habits for these species were described according to field observations and the available literature (Rottmann, 1995; Araya and Millie, 1996; Ippi et al., 2003; Martínez and González, 2004; McGehee and Eitniear, 2006; McGehee and Eitniear, 2007a, 2007b).

\section{Statistical analysis}

The bird species composition, richness and relative abundances, in terms of the total number of individuals recorded in all wetlands within a Sphagnum-dominated peat bog, were determined. The Shannon-Weaver ( $\left.H^{\prime}\right)$ diversity index was calculated (Zar, 1984). A Student's $t$ test was performed to determine if the richness and abundance values of birds in peat bogs were different from those obtained in other types of wetlands (Scheiner and Gurevitch, 1993).

The Jaccard $(\mathrm{Cj})$ index of taxonomic similarity was calculated to explore how similar wetlands and their respective matrices were in terms of their bird-specific compositions (Magurran, 1988). Jaccard values range between 0 and 1 , where 1 indicates complete similarity (equal clustering of species) and 0 indicates dissimilarity (no common or shared species) (Schemnitz, 1980). With this information, the difference in the levels of similarity was tested both within and between two different habitat types, Sphagnum-dominated peat bog wetlands and wetlands without peat bog. A one-way analysis of variance (ANOVA) was performed, and the means were separated according to the Posthoc Tukey's test (Koenen and Gale, 2000). All analyses were performed with the program SPSS 10.0 (SPSS, Chicago, USA, 1999).

\section{Results}

A total of 56 bird species were recorded in the peat bogs and other types of wetlands present on Navarino Island. From the total number of bird species found in these sub-Antarctic wetlands, $66.1 \%$ (37 species) were recorded in Sphagnumdominated peat bog wetlands (Table 2), which constitutes $7.9 \%$ of the birds found in Chile (Martínez and González, 2004) and 23.8\% of the species recorded south of the Beagle Channel (Couve and Vidal, 2000). The species richness values varied between 13 and 21 for peat bog wetlands, while the abundance ranged from 102 to 244 individuals per station and diversity was between 2.29 and 2.68 (Table 2). All three of these variables (richness, abundance and diversity) did not show significant differences $(p>0.05)$ between Sphagnum-dominated peat bogs and wetlands without peat. 
Table 2. Composition, number, relative abundances and species diversity indexes for five peat bog wetlands in the Cape Horn Biosphere Reserve. Additionally, species not registered in Sphagnum-dominated peat bogs but only in other wetland types are indicated.

\begin{tabular}{|c|c|c|c|c|c|c|c|c|}
\hline \multirow[b]{2}{*}{ Family } & \multirow[b]{2}{*}{ Scientific name } & \multicolumn{5}{|c|}{ Sphagnum dominated wetland } & \multirow[b]{2}{*}{ TOTAL } & \multirow[b]{2}{*}{ Relative value } \\
\hline & & $\mathrm{N}^{\circ} 3$ & $\mathrm{~N}^{\circ} 4$ & $\mathrm{~N}^{\circ} 5$ & $\mathrm{~N}^{\mathrm{o}} 6$ & $\mathrm{~N}^{\mathrm{o}} 7$ & & \\
\hline \multirow[t]{7}{*}{ Anatidae } & Anas flavirostris & 3 & 10 & 3 & 6 & 0 & 22 & 0.025 \\
\hline & Anas georgica & 0 & 20 & 11 & 0 & 0 & 31 & 0.035 \\
\hline & Anas sibilatrix & 2 & 0 & 0 & 0 & 0 & 2 & 0.002 \\
\hline & Chloephaga picta & 9 & 10 & 25 & + & 18 & 62 & 0.069 \\
\hline & Chloephaga poliochepala & 0 & 2 & 0 & 0 & 0 & 2 & 0.002 \\
\hline & Lophonetta specularioides & 0 & 2 & 3 & 0 & 0 & 5 & 0.006 \\
\hline & Tachyeres patachonicus & 2 & 2 & 0 & 0 & 0 & 4 & 0.004 \\
\hline Ardeidae & Nycticorax nycticorax & 0 & 0 & + & 0 & 0 & 0 & 0.000 \\
\hline Threskiornithidae & Theristicus melanopis & 0 & 4 & 0 & + & 0 & 4 & 0.004 \\
\hline \multirow[t]{3}{*}{ Falconidae } & Caracara plancus & + & 7 & 4 & 2 & 4 & 17 & 0.019 \\
\hline & Falco sparverius & 1 & 0 & 2 & 0 & 0 & 3 & 0.003 \\
\hline & Milvago chimango & 8 & 6 & 8 & 5 & 7 & 34 & 0.038 \\
\hline \multirow[t]{2}{*}{ Charadriidae } & Charadrius modestus & 0 & 0 & 0 & 0 & 4 & 4 & 0.004 \\
\hline & Vanellus chilensis & 0 & 8 & 2 & 0 & 0 & 10 & 0.011 \\
\hline Scolopacidae & Gallinago paraguaiae & 0 & 0 & 0 & 2 & 0 & 2 & 0.002 \\
\hline Laridae & Larus dominicanus & 2 & 1 & 1 & 0 & 0 & 4 & 0.004 \\
\hline Psittacidae & Enicognathus ferrugineus & 2 & + & 1 & 0 & 0 & 3 & 0.003 \\
\hline Picidae & Campephilus magellanicus & 5 & 1 & 0 & 2 & 0 & 8 & 0.009 \\
\hline \multirow[t]{4}{*}{ Furnariidae } & Aphrastura spinicauda & 54 & 42 & 35 & 49 & 17 & 197 & 0.220 \\
\hline & Cinclodes fuscus & 0 & 0 & 0 & + & + & 0 & 0.000 \\
\hline & Cinclodes patagonicus & 0 & 3 & 1 & 0 & + & 4 & 0.004 \\
\hline & Pygarrhichas albogularis & 4 & 0 & 0 & 3 & 0 & 7 & 0.008 \\
\hline Rhynocriptidae & Scytalopus magellanicus & 0 & 0 & 0 & 2 & 0 & 2 & 0.002 \\
\hline \multirow[t]{6}{*}{ Tyrannidae } & Anairetes parulus & 2 & 1 & 4 & 7 & 0 & 14 & 0.016 \\
\hline & Colorhamphus parvirostris & 0 & 0 & 0 & 2 & 0 & 2 & 0.002 \\
\hline & Elaenia albiceps & 12 & 7 & 3 & 7 & 1 & 30 & 0.034 \\
\hline & Lessonia Rufa & 0 & 0 & 0 & 0 & 0 & 0 & 0.000 \\
\hline & Muscisaxicola maclovianus & 0 & + & + & + & 0 & 0 & 0.000 \\
\hline & Xolmis pyrope & 4 & 6 & 4 & 10 & 14 & 38 & 0.043 \\
\hline Hirundinidae & Tachycineta meyeni & 8 & 22 & 1 & 10 & 1 & 42 & 0.047 \\
\hline \multirow[t]{2}{*}{ Troglodytidae } & Cistothorus platensis & 0 & 0 & 0 & 3 & 0 & 3 & 0.003 \\
\hline & Troglodytes musculus & 6 & 8 & 7 & 21 & 6 & 48 & 0.054 \\
\hline Turdidae & Turdus falckandii & 27 & 37 & 11 & 10 & 3 & 88 & 0.098 \\
\hline \multirow[t]{2}{*}{ Emberizidae } & Phrygilus patagonicus & 21 & 20 & 10 & 12 & 5 & 68 & 0.076 \\
\hline & Zonotrichia capensis & 9 & 20 & 16 & 13 & 15 & 73 & 0.082 \\
\hline Icteridae & Curaeus curaeus & 0 & 0 & 0 & 3 & 0 & 3 & 0.003 \\
\hline \multirow[t]{4}{*}{ Fringillidae } & Carduelis barbata & 11 & 5 & 22 & 13 & 7 & 58 & 0.065 \\
\hline & Species richness & 20 & 23 & 21 & 20 & 13 & & \\
\hline & Total number of birds & 192 & 244 & 174 & 182 & 102 & & \\
\hline & $H^{\prime}\left(\log _{\mathrm{e}}\right)$ & 2.46 & 2.68 & 2.56 & 2.50 & 2.29 & & \\
\hline
\end{tabular}




\begin{tabular}{ll} 
& Not registered in Sphagnum bogs but in other wetland types: \\
Anatidae & Anas platalea \\
& Chloephaga hybrida \\
& Tachyeres pteneres \\
Podicipedidae & Podiceps major \\
& Rollandia rolland \\
Phalacrocoracidae & Phalacrocorax atriceps \\
& Phalacrocorax brasilianus \\
Accipitridae & Accipiter bicolor \\
Rallidae & Feranoaetus melanoleucus \\
Haematopodidae & Falica armillata \\
Scolopacidae & Tringa melanoleuca \\
Stercorariidae & Stercorarius chilensis \\
Laridae & Leucophaeus scoresbii \\
Hirundinidae & Sterna hirundinacea \\
Motacillidae & Pygochelidon cyanoleuca \\
Emberizidae & Anthus correndera \\
Icteridae & Melanodera xanthogramma \\
\hline,+ indicates presence but out of the systematic sampling.
\end{tabular}

The highest similarity values were obtained between wetlands 4 and $5(0.769)$ and wetlands 3 and5 (0.640) (all Sphagnum-dominated peat bogs). In contrast, the lowest values were obtained between wetlands 1 and $10(0.250)$ (wetland 1 was near the sea). Overall, the community similarity values between wetlands indicated that the bird composition in Sphagnum-dominated peat bogs significantly differed from that in wetlands without peat $\left(\mathrm{F}_{2,42}=9.028 ; \mathrm{p}=0.0005\right)$ (Figure 2$)$.

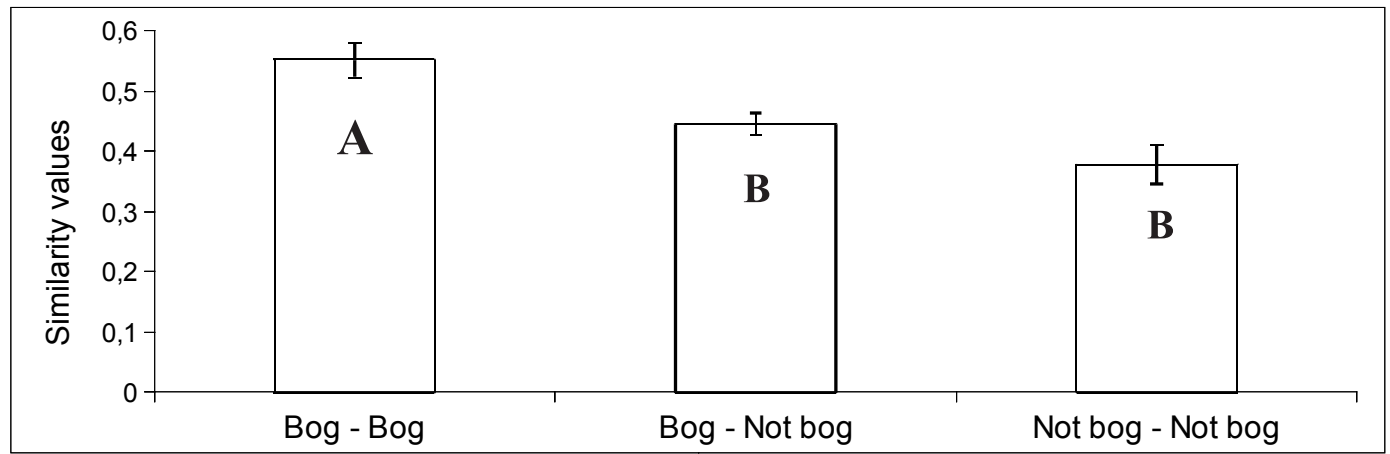

Figure 2. Similarity values (Jaccard Index) for the bird community compositions in wetlands with and without Sphagnumdominated peat bogs. Bars with distinct letters were significantly different according to the Posthoc analysis of Tukey $(\mathrm{F} 2,42=9.028 ; \mathrm{p}=0.0005)$. Small bars are \pm standard deviation.

a lagoon and 10 was a pond at 379 m.a.s.1.) and wetlands 2 and $10(0.250)$ (wetland 2 was a lake
Regarding the guild structure of aquatic and aquatic/terrestrial birds in terms of feeding habits 
and microhabitat association, the most abundant categories were the omnivores that were associated with open waters ( $\mathrm{n}=5$ : Anas flavirostris; A. georgica; Larus dominicanus; Lophonetta specularioides; and Tachyeres patachonicus), followed by the omnivores that were associated with shores ( $\mathrm{n}=3$ : Charadrius modestus; $L$. dominicanus; and Vanellus chilensis) (Table 3).

Table 3. Habitat, feeding habits and microhabitat for birds in peat bogs of the Cape Horn Biosphere Reserve.

\begin{tabular}{|c|c|c|c|}
\hline Species & Habitat $^{1}$ & Feeding habits ${ }^{2}$ & Micro-habitat \\
\hline Anas flavirostris & A & $\mathrm{O}$ & Open waters \\
\hline Anas georgica & A & $\mathrm{O}$ & Open waters \\
\hline Anas sibilatrix & A & $\mathrm{H}$ & Open waters \\
\hline Chloephaga picta & $\mathrm{A} / \mathrm{T}$ & $\mathrm{H}$ & Shores/Open waters \\
\hline Chloephaga poliochepala & $\mathrm{A} / \mathrm{T}$ & $\mathrm{H}$ & Shores/Open waters \\
\hline Lophonetta specularioides & A & $\mathrm{O}$ & Open waters \\
\hline Tachyeres patachonicus & A & $\mathrm{O}$ & Open waters \\
\hline Nycticorax nycticorax & $\mathrm{A} / \mathrm{T}$ & $\mathrm{C}$ & Shores/Coasts \\
\hline Theristicus melanopis & $\mathrm{T}$ & I & \\
\hline Caracara plancus & $\mathrm{T}$ & $\mathrm{C}$ & \\
\hline Falco sparverius & $\mathrm{T}$ & C-I & \\
\hline Milvago chimango & $\mathrm{T}$ & C-I & \\
\hline Charadrius modestus & $\mathrm{A} / \mathrm{T}$ & $\mathrm{O}$ & Shores/Coasts \\
\hline Vanellus chilensis & $\mathrm{A} / \mathrm{T}$ & $\mathrm{O}$ & Shores \\
\hline Gallinago paraguaiae & $\mathrm{A} / \mathrm{T}$ & I & Rushes \\
\hline Larus dominicanus & $\mathrm{A} / \mathrm{T}$ & $\mathrm{O}$ & Shores/Coasts/Open waters \\
\hline Enicognathus ferrugineus & $\mathrm{T}$ & $\mathrm{H}$ & \\
\hline Campephilus magellanicus & $\mathrm{T}$ & I & \\
\hline Aphrastura spinicauda & $\mathrm{T}$ & $\mathrm{I}$ & \\
\hline Cinclodes fuscus & $\mathrm{A} / \mathrm{T}$ & I & Shores \\
\hline Cinclodes patagonicus & $\mathrm{A} / \mathrm{T}$ & I & Shores/Coasts \\
\hline Pygarrhichas albogularis & $\mathrm{T}$ & I & \\
\hline Scytalopus magellanicus & $\mathrm{T}$ & I & \\
\hline Anairetes parulus & $\mathrm{T}$ & I & \\
\hline Colorhamphus parvirostris & $\mathrm{T}$ & I & \\
\hline Elaenia albiceps & $\mathrm{T}$ & I & \\
\hline Lessonia rufa & $\mathrm{T}$ & I & \\
\hline Muscisaxicola maclovianus & $\mathrm{T}$ & I & \\
\hline Xolmis pyrope & $\mathrm{T}$ & I & \\
\hline Tachycineta meyeni & $\mathrm{T}$ & I & \\
\hline Cistothorus platensis & $\mathrm{A} / \mathrm{T}$ & $\mathrm{I}$ & Rushes \\
\hline Troglodytes musculus & $\mathrm{T}$ & I & \\
\hline Turdus falckandii & $\mathrm{T}$ & $\mathrm{O}$ & \\
\hline Phrygilus patagonicus & $\mathrm{T}$ & $\mathrm{H}$ & \\
\hline Zonotrichia capensis & $\mathrm{T}$ & $\mathrm{H}$ & \\
\hline Curaeus curaeus & $\mathrm{T}$ & $\mathrm{O}$ & \\
\hline Carduelis barbata & $\mathrm{T}$ & $\mathrm{H}$ & \\
\hline
\end{tabular}

${ }^{1} \mathrm{~A}$ : aquatic, T: terrestrial.

${ }^{2} \mathrm{C}$ : carnivores, H: herbivores (including granivores), I: insectivores and other invertebrates, O: omnivores. 
Considering all of the recorded species, including the aquatic, aquatic/terrestrial and terrestrial birds, the most frequent feeding habit was that of the insectivores (48.7\%), followed by the omnivores $(23.1 \%)$, herbivores $(17.9 \%)$, and carnivores $(10.3 \%)$ (Table 3$)$.

In relation to the categories of activity, birds were observed flying in $40 \%$ of the cases. Anas sibilatrix, Caracara plancus, Carduelis barbata, Enicognathus ferrugineus and L. dominicanus were the species that presented the highest proportion of birds performing this activity, reaching 74\% of the records. The second most represented category, in relative terms, was the sound record (23\%). Colorhamphus parvirostris, Elaenia albiceps, Pygarrhichas albogularis and Scytalopus magellanicus were detected in high proportions by means of their vocalization (>74\%). Resting $(15 \%)$ was the third most represented category: A. georgica, Curaeus curaeus, and T. patachonicus showed this activity in more than $63 \%$ of the cases. Two species, Aphrastura spinicauda and T. patachonicus, often showed an alarm behavior (>32\%). Campephilus magellanicus (38\%), Cinclodes patagonicus (33\%), L. specularioides $(50 \%)$ and $V$. chilensis $(50 \%)$ were the four species with the highest dedication to feeding. Only one species, Chloephaga poliocephala (33\%), was observed fighting. Finally, only Cistothorus platenses $(20 \%)$ presented courting behavior during the sampling (Table 4).

\section{Discussion}

This work provides new information on the natural history, diversity and community structure of the birds that inhabit Sphagnum-dominated peat bogs in the CHBR. Our results show that, unlike previous works on the avifauna present in peat bogs in other zones in Patagonia (Sielfeld, 1977; Venegas, 1976, 1981, 1991; Guzmán et al. 1986; Venegas and Sielfeld, 1998; Blanco et al., 2004; and Schlatter, 2004), these environments shelter a significant portion of the avian diversity found on Navarino Island in the Cape Horn Biosphere Reserve. Our records of species richness $(n=37)$ in peat bogs is much higher than those obtained in studies conducted farther north in the Magallanes Region (e.g., Venegas, 1976, $\mathrm{n}=3$ species; Guzmán et al., 1986, $\mathrm{n}=6$ species; Blanco et al., 2004, $\mathrm{n}=6$ species; and Schlatter, 2004, $\mathrm{n}=25$ species). In general, the previously mentioned studies consisted of specific samplings of a few days during one season (except Schlatter 2004), which could explain the lower numbers of species recorded, and in turn highlight the value of long-term research programs (Anderson et al., 2008). Furthermore, ecotone zones were considered in our study (e.g., bog-forest, bog-shrub and bog-grassland), and freshwater birds were included; both of these aspects could have influenced the high number of species observed in this study.

The increasing exploitation and consecutive isolation of peat lands have been reported as main factors affecting bird diversity at the landscape scale (Calmé and Desrochers, 2000). In contrast, in the CHBR the mosaic of different habitat types represents a very rare example of the non-fragmented areas in the world (Rozzi et al., 2006). This characteristic of the study area, in addition to our results showing a higher diversity of birds in peat bogs within the CHBR than in other nearby areas, suggests that the importance of peat bog ecosystems for a particular area is probably contingent on the matrix of habitats found in the broader landscape. Consequently, in the CHBR, where peat bogs are more abundant and connected with other heterogenic and undisturbed habitats, this environment could occupy a more prominent role in determining the landscape-level species assemblages of avifauna. Therefore, landscape measures are necessary, but probably not sufficient, to describe the patterns of bird diversity found in the CHBR.

Based on our findings, we put forward that Sphagnum-dominated peat bogs represent a unique wetland habitat for a significant portion of the avian community in the CHBR. This position is supported by the fact that the assemblages found in these peat bogs are highly divergent from those of other wetland types (Similarity index, Figure 2). At the same time, the species composition within peat bogs tends to be the very uniform (i.e., displaying a high degree of similarity among these peat bogs). This result could be interpreted at least in two different ways: (1) when the rest of the wetlands are grouped as "of other type", their intrinsic variability is not being 
Table 4. Relative frequency of activity categories for each bird species recorded in peat bogs of the Cape Horn Biosphere Reserve.

\begin{tabular}{|c|c|c|c|c|c|c|c|c|c|}
\hline Species & $\mathrm{n}$ & Fighting & Feeding & Flying & Alarming & Courting & $\begin{array}{l}\text { Resting or } \\
\text { swimming }\end{array}$ & $\begin{array}{l}\text { Vocalizing } \\
\text { record }\end{array}$ & Total \\
\hline Anairetes parulus & 14 & & 0.18 & 0.36 & & & & 0.45 & 1 \\
\hline Anas flavirostris & 22 & & & 0.47 & & & 0.53 & & 1 \\
\hline Anas georgica & 31 & & & 0.36 & & & 0.64 & & 1 \\
\hline Anas sibilatrix & 2 & & & 1.00 & & & & & 1 \\
\hline Aphrastura spinicauda & 197 & & 0.10 & 0.17 & 0.47 & & & 0.26 & 1 \\
\hline Campephilus magellanicus & 8 & & 0.38 & 0.50 & & & & 0.13 & 1 \\
\hline Caracara plancus & 17 & & & 0.75 & & & 0.19 & 0.06 & 1 \\
\hline Carduelis barbata & 58 & & 0.04 & 0.76 & & & 0.08 & 0.12 & 1 \\
\hline Charadrius modestus & 4 & & & 0.50 & & & 0.50 & & 1 \\
\hline Chloephaga picta & 62 & & 0.05 & 0.55 & & & 0.40 & & 1 \\
\hline Chloephaga poliochepala & 2 & 0.33 & & 0.33 & & & 0.33 & & 1 \\
\hline Cinclodes fuscus* & 0 & & & & & & & & 0 \\
\hline Cinclodes patagonicus & 4 & & 0.33 & 0.50 & & & 0.17 & & 1 \\
\hline Cistothorus platensis & 3 & & 0.20 & 0.40 & & 0.20 & 0.20 & & 1 \\
\hline Colorhamphus parvirostris & 2 & & & & & & & 1.00 & 1 \\
\hline Curaeus curaeus & 3 & & & & & & 1.00 & & 1 \\
\hline Elaenia albiceps & 30 & & & 0.09 & & & & 0.91 & 1 \\
\hline Enicognathus ferrugineus & 3 & & & 1.00 & & & & & 1 \\
\hline Falco sparverius & 3 & & & 0.67 & & & 0.33 & & 1 \\
\hline Gallinago paraguaiae & 2 & & & 0.50 & & & 0.50 & & 1 \\
\hline Larus dominicanus & 4 & & & 1.00 & & & & & 1 \\
\hline Lessonia rufa* & 0 & & & & & & & & 0 \\
\hline Lophonetta specularioides & 5 & & 0.50 & & & & 0.50 & & 1 \\
\hline Milvago chimango & 34 & & & 0.71 & & & 0.14 & 0.14 & 1 \\
\hline Muscisaxicola maclovianus * & 0 & & & & & & & & 0 \\
\hline Nycticorax nycticorax * & 0 & & & & & & & & 0 \\
\hline Phrygilus patagonicus & 68 & & 0.07 & 0.66 & 0.03 & & & 0.24 & 1 \\
\hline Pygarrhichas albogularis & 7 & & 0.25 & & & & & 0.75 & 1 \\
\hline Scytalopus magellanicus & 2 & & & & & & & 1.00 & 1 \\
\hline Tachycineta meyeni & 42 & & 0.19 & 0.71 & & & 0.05 & 0.05 & 1 \\
\hline Tachyeres patachonicus & 4 & & & & 0.33 & & 0.67 & & 1 \\
\hline Theristicus melanopis & 4 & & & 0.67 & & & 0.33 & & 1 \\
\hline Troglodytes musculus & 48 & & 0.08 & 0.15 & 0.21 & & 0.03 & 0.54 & 1 \\
\hline Turdus falckandii & 88 & & 0.02 & 0.34 & 0.27 & & 0.23 & 0.14 & 1 \\
\hline Vanellus chilensis & 10 & & 0.50 & 0.25 & 0.25 & & & & 1 \\
\hline Xolmis pyrope & 38 & & 0.06 & 0.44 & & & 0.25 & 0.25 & 1 \\
\hline Zonotrichia capensis & 73 & & 0.21 & 0.34 & & & 0.25 & 0.21 & 1 \\
\hline Total number of birds & 894 & & & & & & & & \\
\hline
\end{tabular}

* Species recorded out of systematic counts.

considered, as the different types of associated habitats (shrubs, rushes, forest, grassland, etc.) should be considered; this information would in turn define different types of assemblages that do not necessarily need to be similar; or (2) that peat bogs actually tend to be more similar 
to each other than do "other types" of wetlands in terms of their specific composition. Consequently, and regardless the first alternative, our study indicates that peat bogs represent a distinct habitat within the sub-Antarctic landscape matrix whose biodiversity is insufficiently studied and has previously been unappreciated. However, the underlying mechanisms explaining the biodiversity present in peat bogs, and the organization and processes involved, still need to be further studied (Arroyo et al. 2005).

The bird assemblage that used peat bogs and their ecotones included mainly insectivores (e.g., G. paraguaiae) but also species from a complete suite of other feeding guilds, including omnivores (e.g., C. modestus), herbivores (e.g., C. picta), granivores (e.g., Phrygilus patagonicus) and carnivores (e.g., Nycticorax nycticorax). Community composition is known to be strongly related to food availability (Cody, 1981), a factor that might be relevant for birds in the Sphagnum wetlands as well (Guzmán et al., 1986). This finding also agrees with what has been reported by Schiavini (2000), who associates the presence of birds in peat bogs mainly to food searching.

In general, in peat bog systems small birds (insectivores) are predominant; these species must feed frequently and, therefore, must have a food source that allows them to feed at regular intervals (Griffiths et al., 1982; Guzmán et al. 1986). The presence of a high proportion of small birds in peat bogs may indicate that these environments have a reliable food source, at least for the predominant insectivorous species. These species form the dominant feeding guild in subAntarctic wetlands during the coldest months, when wetlands are completely frozen (Ibarra et al., 2009b). In the case of the herbivorous species (excluding the granivorous species such as $P$. patagonicus or C. barbata) and omnivores species, fundamentally the Anatidae, food is frequently obtained from the open waters or shores where there might be a higher production of food resources, in contrast to the fact that Magellanic peat bogs have been considered to be a system of low productivity where plant species present scarce palatability (Pisano, 1977).

In the case of reproduction, Matteazzi (1997) and Schiavini (2000) pointed out that the peat bog-forest ecotone is a nesting site for non-passeriform species such as C. picta and G. paraguaiae. C. picta usually nests in inland peat bog wetlands in the CHBR (Ibarra et al., 2009b), while $G$. paraguaiae was commonly recorded in peat bogs during the spring and summer seasons, in twilight, performing nuptial flights with a characteristic buzz that is made with the tail. This reproductive behavior is characteristic for this Scolopacidae (Rottmann, 1995). The results for the activity categories also allowed for the identification of $C$. platensis while performing courting activity and $C$. poliocephala while fighting for territory during the breeding season. Likewise, the records of C. magellanicus were obtained in a transition bog-forest, even though this species is always associated with the presence of old-growth trees. This Picidae is usually found in the old-growth forests of Cape Horn (Arango et al., 2007), which constitute the main matrix of Sphagnum-dominated peat bogs in the Magallanes (Arroyo et al., 2005).

In light of the fact that, currently, Sphagnumdominated peat bogs are under a growing pressure for extraction in southern South America, conservation-oriented policies and policies for sustainable use should consider their high value for feeding, reproduction and sheltering for an important diversity of birds. According to Arroyo et al. (2005), peat bogs and forests are intrinsically linked at the ecosystem level in austral South America; therefore, the destiny for peat bogs will determine the future of Southern temperate forests, and vice versa.

\section{Acknowledgements}

This work was financed by the project FPA 12001-06 of CONAMA, granted to the Omora Foundation, and by Wildlife Trust Alliance. The Institute of Ecology and Biodiversity (IEB) also provided financial contributions through grant ICM P05-002, and the Puerto Williams Branch-UMAG provided logistic support to the team. Special thanks to A. Barreau, E. Firmani, G. González and S. McGehee for their support in the field. The comments by B. Latorre helped to improve preliminary versions of the manuscript. JT Ibarra and TA Altamirano are CONICYT research grant holders. This study is 
part of the long-term programs of conservation and research of the Omora Ethnobotanical Park, the scientific research center of the Cape Horn
Biosphere Reserve and the founding member of Chile's long-term socio-ecological research network (www.ieb-chile.cl/ltser).

\section{Resumen}

Ibarra, J.T., C.B. Anderson, T.A. Altamirano, R. Rozzi y C. Bonacic. 2010. Diversidad y singularidad de la avifauna en turberas esfagnosas australes de la Reserva de Biosfera Cabo de Hornos, Chile. Cien. Inv. Agr. 37(1):29-43. Las turberas esfagnosas que se encuentran fuertemente embebidas en la matriz de bosques templados australes, se utilizan de forma creciente en agricultura. Sin embargo, el conocimiento de su biodiversidad es escaso. Más aún, zonas remotas del sur de Chile donde se encuentran las turberas, como la Reserva de Biosfera Cabo de Hornos ( $\left.\mathrm{RBCH}, 54-55^{\circ} \mathrm{S}\right)$, donde las aves constituyen el grupo de vertebrados más diverso y representativo, aún han sido escasamente estudiadas. Con el objetivo de aportar en su conocimiento en la $\mathrm{RBCH}$, se estudió la diversidad del ensamble de aves en turberas esfagnosas de la isla Navarino. Se exploró si su composición específica es igual al de los humedales sin turbera, probando si las turberas constituyen o no un hábitat singular para las aves. También se clasificó a las 37 especies de aves registradas en estos hábitats de acuerdo a la estructura de gremios. Los valores de similitud taxocenótica señalaron que la composición de aquellos con turbera difirió de aquellos sin turbera, sugiriendo que este hábitat es singular para las aves. El tipo de alimentación más frecuente fue la insectivoría (48,7\%), seguido por la omnivoría $(23,1 \%)$. Los resultados muestran que, a diferencia de lo señalado en trabajos previos sobre aves de turberas, estos ambientes constituyen un humedal-hábitat singular para la alimentación, reproducción y refugio de algunas especies en la RBCH. De esta manera, la conservación y uso racional de turberas debe considerar el valor que tienen como hábitat para la biodiversidad a escala de paisaje, especialmente para las aves del extremo sur americano.

Palabras clave: Ensamble, humedales, isla Navarino, Patagonia, Reserva de Biosfera Cabo de Hornos, Sphagnum spp.

\section{References}

Anderson, C.B., and R. Rozzi. 2000. Bird assemblages in the southernmost forests in the world: Methodological variations for determining species composition. Anales del Instituto de la Patagonia 28:89-100.

Anderson, C.B., R. Rozzi, C. Elphick, and S. McGehee. 2002. El programa Omora de anillamiento de aves en los bosques subantárticos: la estandarización del tamaño de anillos apropiados para las aves de la región de Magallanes. Boletín Chileno de Ornitología 9:2-11.

Anderson, C.B., R. Rozzi, J.C. Torres-Mura, S.M. McGehee, M.F. Sherriffs, E. Schüttler, and A.D. Rosemond. 2006. Exotic vertebrate fauna in the remote and pristine sub-Antarctic Cape Horn Archipelago region of Chile. Biodiversity and Conservation. 10:3295-3313.
Anderson, C.B., R. Rozzi, G.E. Likens, J.R. Gutiérrez, A. Poole, and J.J. Armesto. 2008. Using longterm socio ecological study sites to integrate research with society. Environmental Ethics 30:295-312.

Arango, X., R. Rozzi, F. Massardo, C.B. Anderson, and J.T. Ibarra. 2007. Descubrimiento e Implementación del Pájaro Carpintero Gigante (Campephilus magellanicus) como especie carismática: una aproximación biocultural para la conservación en la Reserva de Biosfera Cabo de Hornos. Magallania 35:71-88.

Arroyo, M.T.K, M. Mihoc, P. Pliscoff, and M. Arroyo-Kalin. 2005. The Magellanic Moorland. Pages 424-445. In: L.H., Fraser, and P.A. Keddy (eds.). The World's Largest Wetlands: Ecology and Conservation. Cambridge University Press, London, UK.

Barros, A. 1971. Aves observadas en las islas Picton, Nueva, Lennox y Navarino oriental. Anales del 
Instituto de la Patagonia 2:166-180.

Barros, A. 1976. Nuevas aves observadas en las islas Picton, Nueva, Lennox y Navarino oriental. Anales del Instituto de la Patagonia 7:89-193.

Blanco, D.E., V.M. De la Balze, and G. Pugnali. 2004. Avifauna de las turberas del centro de la Isla de Tierra del Fuego, Argentina. Pages 113118. In: Blanco, D.E., and D.M. de la Balze (eds.). Los Turbales de la Patagonia: Bases para su Inventario y la Conservación de la Biodiversidad. Wetlands International, Publicación 19, Buenos Aires, Argentina.

Brown, C.E., C.B. Anderson, S. Ippi, M.F. Sherriffs, R. Charlin, S.M. McGehee, and R. Rozzi. 2007. The autecology of the fío-fío (Elaenia albiceps Lafresnaye \& D'Orbigny) in Sub-Antarctic forests of the Cape Horn Biosphere Reserve, Chile. Anales Instituto Patagonia 35:29-40.

Calmé, S., and A. Desrochers. 2000. Biogeographic aspects of the distribution of bird species breeding in Québec's peatlands. Journal of Biogeography 27:725-732.

Cody, M.L. 1981. Habitat selection in birds: the roles of vegetation structure, competitors and productivity. Bioscience 31:107-113.

Couve, E., and C. Vidal. 2000. Aves del Canal Beagle y Cabo de Hornos. Fantástico Sur Birding LTDA, Punta Arenas, Chile. 266 pp.

de la Balze, V.M., D.E. Blanco, and N. Loekemeyer. 2004. Avifauna de las turberas del centro de la Isla de Tierra del Fuego, Argentina. Pages 129140. In: Blanco, D.E., and D.M. de la Balze (eds.). Los Turbales de la Patagonia: Bases para su Inventario y la Conservación de la Biodiversidad. Wetlands International, Publicación 19, Buenos Aires, Argentina.

di Castri, F., and E. Hajek. 1976. Bioclimatología de Chile. Vicerrectoría de Comunicaciones, Pontificia Universidad Católica de Chile. Santiago, Chile. 129 pp.

González, A., and P. Victoriano. 2005. Aves de los humedales costeros de la zona de Concepción y alrededores. Pages 485-497. In: Smith-Ramírez, C., J. Armesto, and C. Valdovinos (eds.). Historia, Biodiversidad y Ecología de los Bosques Costeros de Chile. Editorial Universitaria, Santiago, Chile.

Guzmán, L., A. Atala, and C. Venegas. 1986. Composición Específica y Estructura de la Comunidad de Aves de Verano en el Complejo de la Tundra Magallánica. Anales del Instituto de la
Patagonia 16:75-86.

Griffiths, A.M., W.R. Siegfred, and R.W. Abrams. 1982. Ecological structure of a pelagic seabird community in the southern ocean. Polar Biology 1:39-46.

Hauser, A. 1996. Los depósitos de turba en Chile y sus perspectivas de utilización. Revista Geológica de Chile 23:217-229.

Henríquez, J.M. 2004. Estado de la turba esfagnosa en Magallanes. Pages 93-104. In: Blanco, D.E., and D.M. de la Balze (eds.). Los Turbales de la Patagonia: Bases para su Inventario y la Conservación de la Biodiversidad. Wetlands International, Publicación 19, Buenos Aires, Argentina.

Humphrey, P.S., D. Bridge, P.W. Reynolds, and R.T. Peterson. 1970. Preliminary Smithsonian Manual, Birds of Isla Grande (Tierra del Fuego). Smithsonian Institution. Washington D.C., USA. 411 pp.

Ibarra, J.T., L. Fasola, D.W. Macdonald, R. Rozzi, and C. Bonacic. 2009a. Invasive American mink Mustela vison in wetlands of the Cape Horn Biosphere Reserve, southern Chile: what are they eating? Oryx 43:87-90.

Ibarra, J.T., R. Rozzi, H. Gilabert, C.B. Anderson, S.M. McGehee, and C. Bonacic. 2009b. Dinámica estacional y patrones de distribución de la avifauna asociada a humedales subantárticos en la Reserva de Biosfera Cabo de Hornos (54-55 $\left.{ }^{\circ} \mathrm{S}\right)$. Ornitolología Neotropical 20:321-337.

Ippi, S., C.B. Anderson, R. Rozzi, and C.F. Elphick. 2009. Annual variation of abundance and composition in forest bird assemblages on Navarino Island, Cape Horn Biosphere Reserve, Chile. Ornitolología Neotropical 20 (2): 231-245.

Ippi, S., and R. Rozzi. 2004. Actividad nocturna y diurna del Concón (Strix rufipes) en los bosques del Cabo de Hornos. Boletín Chileno de Ornitología 10:9-12.

Koenen, M.T., and S. Gale. 2000. Effects of fire on birds in Paramo habitat of Northern Ecuador. Ornitología Neotropical 11:155-163.

Lappalainen, E. 1996. Global Peat Resources. UNESCO Geological Survey of Finland.

Finland Peat Society.

Magurran, A. 1988. Ecological Diversity and its measurement. Princeton University Press, NJ, USA. 179 pp.

Martínez, D., and G. González. 2004. Las Aves de Chile: Nueva Guía de Campo. Ediciones del Naturalista, Santiago, Chile. 620 pp. 
Matteazzi, H.G. 1997. Relevamiento de Fauna Silvestre Cuartel "Lainez Oeste", Diciembre 1996. Departamento Fauna Silvestre y Ambientes Naturales, Subsecretaría de Recursos Naturales y Ambiente Humano, Provincia Tierra del Fuego, Argentina.

McGehee, S.M., R. Rozzi, C.B. Anderson, S. Ippi, R.A. Vásquez, and S. Woodland. 2004. Latesummer presence of the Patagonian tyrant, Colorhamphus parvirostris (Darwin) in Navarino island, Cape Horn County, Chile. Anales del Instituto de la Patagonia 32:25-33.

McGehee, S.M., and J.C. Eitniear. 2006. Field verification of Zimmer's wing-formula for identification of Elaenia albiceps chilensis. Boletín SAO 16:58-63.

McGehee, S.M., and J.C. Eitniear. 2007a. Diet of the patagonian Sierra-finch (Phrygilus patagonicus) on Navarino island, Chile. Ornitología Neotropical 18:449-452.

McGehee, S.M., and J.C. Eitniear. 2007b. Consumption of leñadura (Maytenus magellanica) seeds by three primarily insectivorous bird species. Anales del Instituto de la Patagonia 35:71-73.

Mittermeier, R.A., C.G. Mittermeier, P. Robles gil, J.D. Pilgrim, W.R. Konstant, G.A.B. Dafonseca, and T.M. Brooks (eds.). 2002. Wilderness: Earth`s Last Wild Places. CEMEX-Conservation International, Mexico. 576 pp.

Moore, D.M. 1983. Flora of Tierra del Fuego. Anthony Nelson, England y Missouri Botanical Garden, USA. 396 pp.

Olrog, C.C. 1950. Mamíferos y Aves del Archipiélago de Cabo de Hornos. Acta Zoológica Lilloana, Tucumán, Argentina 9:505-532.

Oustalet, E. 1891. Oiseaux. Mission Scientifique du Cap Horn 1882-1883. Zoologie 6 (B): 1-341.

Pisano, E. 1977. Fitogeografía de Fuego-Patagonia Chilena. Comunidades vegetales entre las latitudes $52^{\circ}$ y $56^{\circ} \mathrm{S}$. Anales del Instituto de la $\mathrm{Pa}$ tagonia 8:121-250.

Ralph, C.J., S. Droege, and J.R. Sauer. 1995. Managing and monitoring birds using point counts : Standards and applications. Pages 161-68. In: Monitoring bird populations by point counts. C. J. Ralph, J. R. Sauer, and S. Droege (eds.). Gen. Tech. Rep. PSW-TR-149. Albany, California: Pacific Southwest Research Station, Forest Service, U.S. Department of Agriculture.

Ramírez, C., and C. San Martín. 2006. Ecosistemas Dulceacuícolas. Pages 112-124. In: CONAMA (eds). Biodiversidad de Chile: Patrimonio y De- safíos. Ocho Libros Editores, Santiago, Chile.

Reynolds, P.W. 1935. Notes on the Birds of Cape Horn. Ibis (Series 13) 5:65-101.

Roig, C.E., F.A. Roig, L. Collado, A. Coronato, E. Martínez Carretero, and V. Barrios. 2001. Inventario de los turbales de la zona centro de la provincia de Tierra del Fuego. Informe final. CFI y Subsecretaría de Recursos Naturales, provincia de Tierra del Fuego, Antártida e Islas del Atlántico Sur. Ushuaia, Argentina. 102 pp.

Rottmann, J. 1995. Guía de identificación de aves de ambientes acuáticos. Unión de Ornitólogos de Chile, Santiago, Chile. 80 pp.

Rozzi, R., D. Martínez, M.F. Willson, and C. Sabag. 1996a. Avifauna de los bosques templados de Sudamérica. Pages 135-152. In: Armesto, J.J., C. Villagrán, and M.T.K. Arroyo (eds.). Ecología de los Bosques Nativos de Chile. Editorial Universitaria, Santiago, Chile.

Rozzi, R., J. Armesto, A. Correa, JC. Torres-mura, and M. Sallaberry. 1996b. Avifauna de bosques primarios templados en islas deshabitadas del archipiélago de Chiloé, Chile. Revista Chilena de Historia Natural 69:125-139.

Rozzi, R., F. Massardo, A. Berghöfer, C.B. Anderson, A. Mansilla, M. Mansilla, J. Plana, U. Berghöfer, P. Araya, and E. Barros. 2006. Reserva de Biosfera Cabo de Hornos: Documento de Base para la Incorporación del Territorio Insular del Cabo de Hornos a la Red Mundial de Reservas de Biosfera. Programa MaB-Unesco. Ediciones de la Universidad de Magallanes, Punta Arenas, Chile. 274 pp.

Scheiner, S.M., and J. Gurevitch. 1993. Design and Analysis of Ecological Experiments. Chapman and Hall, NY, USA. 429 pp.

Schemnitz, S.D. 1980. Wildlife Management Techniques Manual. Fourth Edition. The Wildlife Society, USA. 703 pp.

Schiavini, A. 2000. Composición faunística de las turberas de Tierra del Fuego. Las Aves. Pages 8384. In: Coronato, A., and C. Roig (eds.). Curso Taller Sobre Conservación de Ecosistemas a Nivel Mundial con Enfasis en las Turberas de Tierra del Fuego. Ushuaia, Tierra del Fuego, Argentina.

Schlatter, R.P. 2004. Fauna de Turberas de la XII Región y Tierra del Fuego. Pages 107-112. In: Blanco, D.E., and D.M. de la Balze (eds.). Los Turbales de la Patagonia: Bases para su Inventario y la Conservación de la Biodiversidad. Wetlands International, Publicación 19, Buenos Aires, Argentina.

Schüttler, E., J.T. Ibarra, B. Gruber, R. Rozzi, and 
K. Jax. 2010. Abundance and habitat preferences of the southernmost population of mink: Implications for managing a recent island invasion. Biodiversity and Conservation 19:725-743.

Sielfeld, W.H. 1977. Reconocimiento Macrofaunístico Terrestre en el Área de Seno Ponsonby (Isla Hoste). Anales del Instituto de la Patagonia 8:275-296.

Venegas, C. 1976. Observaciones ornitológicas en la Tundra Magallánica I.-Recuento descriptivo del área y de las observaciones aviales entre los paralelos $51^{\circ} 31^{\prime} \mathrm{S}$ y $52^{\circ} 09^{\prime} \mathrm{S}$. Anales del Instituto de la Patagonia 7:171-184.

Venegas, C. 1981. Aves de las Islas Wollaston y Bayly, Archipiélago del Cabo de Hornos. Anales del Instituto de la Patagonia 12:213-219.
Venegas, C. 1991. Ensambles Avifaunísticos Estivales del Archipiélago Cabo de Hornos. Anales del Instituto de la Patagonia 20:69-82.

Venegas, C., and J. Jory. 1979. Guía de campo para las aves de Magallanes. Publicaciones del Instituto de la Patagonia. Serie Monografías 11. Punta Arenas, Chile. 253 pp.

Venegas, C., and W. Sielfeld. 1998. Catálogo de los Vertebrados de la Región de Magallanes y Antártica Chilena. Ediciones de la Universidad de Magallanes, Punta Arenas, Chile. 122 pp.

Zar, J.H. 1984. Biostatistical Analysis. 2nd edition. Prentice Hall. NJ, USA. 71 pp. 
